\title{
An insight into Bronze Age subsistence strategy in forested Carpathian foothills, based on plant macro-remains
}

\author{
Magda Kapcia $^{1} \cdot$ Aldona Mueller-Bieniek $^{1}$ (D) \\ Received: 6 August 2017 / Accepted: 20 September 2018 / Published online: 4 October 2018 \\ (C) The Author(s) 2018
}

\begin{abstract}
Lipnik site 5, from which a storage pit dated to the Middle Bronze Age (ca. 1400-1100) was studied, gave more than 70 plant taxa in the extraordinarily well-preserved charred assemblage. In the paper, a detailed description of selected plants is presented followed by environmental interpretation. Acorns (Quercus) dominated in volume and proso millet (Panicum miliaceum) in the number of specimens. The first large find of that late incomer north of the Carpathian Mountains is presented here. The pit users also used hulled wheat (einkorn, emmer, and spelt); barley; and probably peas. In the pit, a large number of grassland plants were noted accompanied by a very few remains of aquatic (Elatine) and forest herbaceous plants (Astrantia major). Weeds and ruderal plants were also present. The composition of plant remains is very unusual for this type of archeological feature, suggesting a mixed type of food strategy for its users, dominated by plant gathering and animal husbandry. The site is located in a newly settled ecotone zone, on the margin of fertile loess areas and mountain foothills.
\end{abstract}

Keywords Fruits $\cdot$ Seeds $\cdot$ Millet $\cdot$ Acorns $\cdot$ Grassland plants $\cdot$ Lipnik $\cdot$ The Trzciniec culture $\cdot$ SE Poland

\section{Introduction}

In most Polish archeological sites, plant remains were preserved through contact with high temperature (charred, carbonized) while uncharred remains of differing degrees of decomposition are usually interpreted as modern contamination of past assemblages (Lityńska-Zając and Wasylikowa 2005; Pearsall 2009; Mueller-Bieniek 2011). High temperature usually influences seed and fruit morphology, both in shape and surface view. Additionally, taxonomical composition of charred archeobotanical assemblages is strongly influenced by past economic activity of the settlers representing only a small part of plant remains present at any site at the time of its occupation (Jacomet et al. 1989; van der Veen 2007; Colledge and Conolly 2014; Mueller-Bieniek et al. 2015a). The studied material from a Bronze Age storage pit at Lipnik site 5 was collected during excavation because of the large number of charred acorn

Electronic supplementary material The online version of this article (https://doi.org/10.1007/s12520-018-0720-9) contains supplementary material, which is available to authorized users.

Aldona Mueller-Bieniek

a.mueller@botany.pl

1 W. Szafer Institute of Botany, Polish Academy of Sciences, Lubicz 46, 31-512 Kraków, Poland remains, well visible during field work (Przybyła and Blajer 2008). Two small subsamples of the soil taken from the pit were analyzed showing extraordinarily good preservation of the charred remains and very considerable taxonomical diversity (Bieniek 2008), which is exceptional for a storage pit, which usually contains crop deposits (Lityńska-Zając 2005). A detailed morphological study of charred archeobotanical remains allowed paleoecological and paleoeconomical interpretations of the assemblage. In the studied samples, fruits, seeds, buds, and wood charcoal were found. In the paper, we will focus on plant macro-remains excluding acorns (Kapcia and MuellerBieniek 2017) and wood charcoal.

\section{Site description}

Lipnik, district Przeworsk (N: 49 59' 37.16"; E: $22^{\circ} 18^{\prime}$ $39.44^{\prime \prime}$ ) is located within a loess plateau called the Kańczuga Plateau (Fig. 1) between the Wisłoka and the San valleys close to its border with the higher elevated, hilly area, which belongs to the Carpathian foothills. It is a part of the Rzeszów Upland (Podgórze Rzeszowskie) also known as the Foreland Loess Plateau (Czopek 2003; Lanczont et al. 2003). Geologically, it is a part of the Sandomierz Basin. The main river of the region is the Eastern Mleczka, a tributary of the Wisłok River. The 
Fig. 1 Location of the Lipnik site

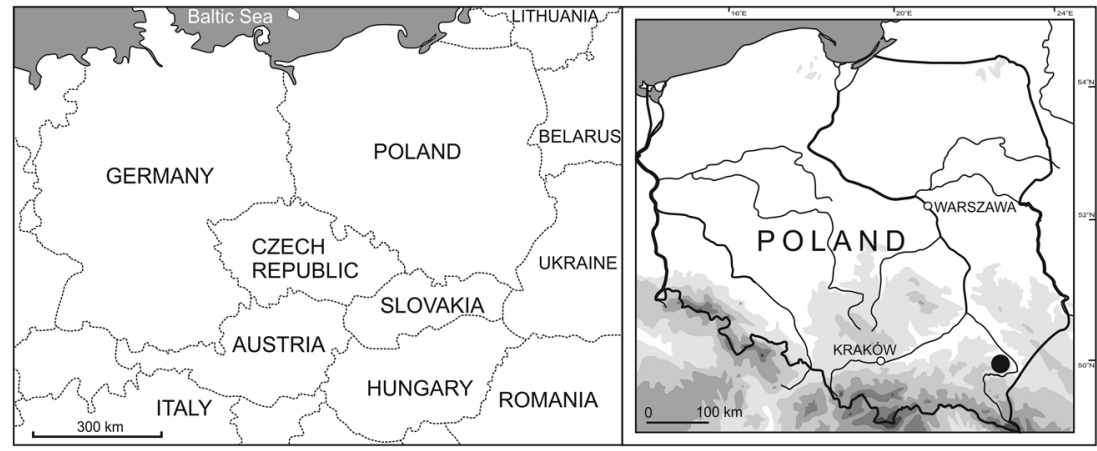

altitude of the region varies between 180 and $300 \mathrm{~m}$ above sea level and has non-uniform surface features. The central part of the region is slightly undulating and crossed by river valleys; to the north, it is sharply defined by the Wisłoka valley; and to the east, it is mildly bordered by the San valley (Lanczont et al. 2001, 2003). To the south it adjoins the Dynów Foothills of the Carpathian Mountains (Kondracki 2000). In the vicinity of the site, several Bronze Age archeological sites were noted (Przybyła and Blajer 2008) as well as early Neolithic ones (Przybyła pers. comm.). Nevertheless, the Lipnik site is located between the loess upland and the previously unsettled Dynów Foothills. Such a location allowed for the exploitation of two different environments.

During the last cold stage of the Pleistocene, the Kańczuga Plateau remained approximately $350 \mathrm{~km}$ beyond the maximum extent of the Scandinavian ice sheet and at this time, a thick layer of loess was deposited upon older, mostly sandy Quaternary materials. The area is mainly covered by brown earths on sedimentary rocks and podzols created on loess and other types of dusty bedrock (Musierowicz 1958; Dobrzański et al. 1999).

The climate of Kańczuga Plateau in the neighborhood of Lipnik (ca. $50^{\circ} \mathrm{N}$ latitude, and $22^{\circ} 18^{\prime} \mathrm{E}$ longitude) is relatively continental as reflected mainly in annual precipitation, reaching up to $650 \mathrm{~mm}$, most of it occurring during the summer months (400-450 mm) and the mean annual amplitude of temperature being higher than $21^{\circ} \mathrm{C}$. The mean monthly temperature over the course of a year ranges between 7.5 and $8^{\circ} \mathrm{C}$, the mean temperature of January ranges from -3.5 to $-3{ }^{\circ} \mathrm{C}$ (min. $\left.36^{\circ} \mathrm{C}\right)$, and in July, it ranges from 17.5 to $18^{\circ} \mathrm{C}\left(\max .+33^{\circ} \mathrm{C}\right)$. The duration of winter is between 80 and 90 days, with snow cover between 50 and 60 days (based on data for 1961-1995) (Koźmiński and Michalska 2001; Klimek et al. 2006).

The area is currently covered mainly by fields, orchards and mixed forests. Without intensive human influence, the area would be overgrown by mixed (Tilio-Carpinetum, Dentario glandulosae-Fagetum) and riparian forests (Ficario-Ulmetum chrysosplenietosum and Alnetum incanae) (Matuszkiewicz 2008). In the past, during the Subboreal period, when the settlement in Lipnik site developed, the surrounding area was most probably covered by mixed forest with spruce (Picea), oak (Quercus), hornbeam (Carpinus), beech (Fagus), fir (Abies), and lime (Tilia) (Zernickaya et al. 2003; Kołaczek 2011). Nevertheless, a local signature of pollen data derived from nearby localities must be underlined. Human influence at this time was visible in pollen diagrams via increasing values of pioneer trees and shrubs (Betula, Alnus, Salix) as well as grassland plants. The activity of Bronze Age settlers can also be detected in the increase in soil erosion and intensification of slope processes in river valleys reflected in the deposition of silts with organic laminations (Klimek et al. 2006) or charcoal layers (Mamakowa and Wójcik 1999), and a large percentage of corroded sporomorphs (Kołaczek 2011). From 3490 to 3230 uncal. years bp, cooling and increasing humidity were noted, which is contemporary with the development of the Bronze Age Mierzanowice and Trzciniec cultures (Lanczont et al. 2003). According to Starkel et al. (2013), in the territory of Poland, the short cooling phase is dated to ca. $1500 \mathrm{cal}$. BC. This cooling phase, which began around 3500 cal. BP and lasted for at least 300 years, was also observed in the Baltic Sea sediments (Warden et al. 2017). Acorns from the analyzed sample are dated to $3015 \pm 35$ uncal. bp; 1392 1128 cal. BC with $95 \%$ of probability (Poz-19,925).

The Bronze Age settlement complex in Lipnik extends to $3.4 \mathrm{~km}^{2}$. Excavations carried out in 1998-2005 covered an area of almost 0.4 ha and resulted in the discovery of more than 500 structures originating from the period between the Middle Bronze Age (ca. 1600 BC) and the Early Iron Age (ca. $400 \mathrm{BC}$ ). The studied feature, number 302, located in the NE part of the excavated area, was archeologically and radiocarbon dated to the late phase of the Trzciniec culture (ca. 1400 $1100 \mathrm{cal}$ BC). The pit had a flat bottom $(130 \mathrm{~cm}$ below the modern ground surface) covered partially with a thin clay layer, which in turn was covered with a layer of dark soil, up to $20-\mathrm{cm}$ thick and saturated with numerous small daub pieces and macroscopically visible charred plant remains (Fig. 2) (Przybyła and Blajer 2008).

\section{Material and method}

Four subsamples were taken from the pit under discussion. Two small subsamples (ca. 11 of volume each) taken from a depth of 115-130 cm were briefly analyzed in 2007 (Bieniek 
Fig. 2 The Middle Bronze Age storage pit 302, Lipnik site 5. a Profile. b Lower sample taken as a monolith with visible charred acorns (photos W. Blajer, M. Moskal-del Hoyo)

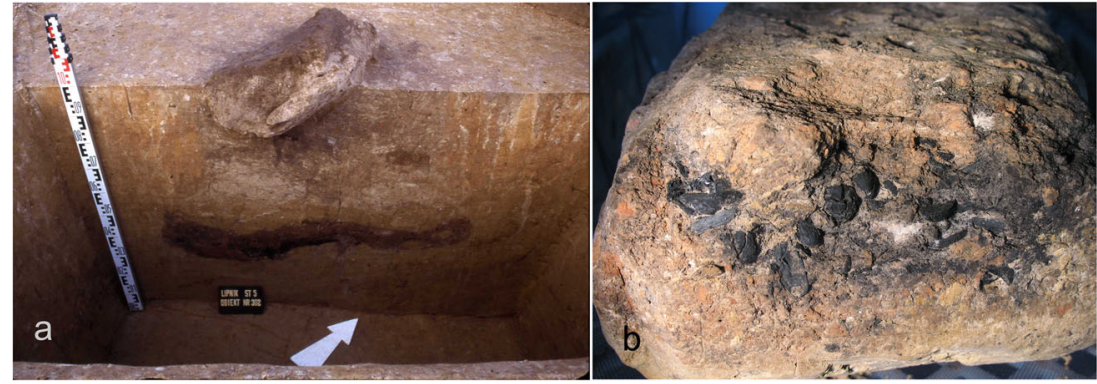

2008). Most of the data presented in this paper come from two subsamples studied recently taken from a depth of 90-115 cm (upper sample) and of 115-130 cm. Three subsamples from the same layer $(115-130 \mathrm{~cm})$ were combined into one sample (the lower sample). Their combined volume reached 201 , the same as the sample taken from the upper layer. In the first stage of sample preparation, some of the soil was sieved, using a manual flotation method, over sieves with 0.2 - and $0.5-\mathrm{mm}$ mesh size. It appeared that the fraction smaller than $0.5 \mathrm{~mm}$, caught by the sieve $0.2 \mathrm{~mm}$, contained only unrecognizable charcoal dust which could not be identified. The rest of the material was wet sieved using $0.5-\mathrm{mm}$ mesh sieves. The heavy fraction was then washed using a net of ca. 1-mm mesh size to collect large mineralized and partly mineralized remains, bones, and other artifacts.

The dried plant material was sorted and identified using a binocular microscope (magnification of up to $\times 60$ ) and a scanning electron microscope (SEM). All specimens were charred, only one single uncharred item was present and was treated as modern contamination. Plant remains were identified in the W. Szafer Institute of Botany, Polish Academy of Sciences in Kraków, using available modern and fossil comparative materials and relevant keys and seed atlases and floras. Morphological names and characters are given mostly after Bojňanský and Fargašová (2007) and on the basis of personal observations and other keys and atlases cited in the text. Botanical names follow Mirek et al. (2002).

\section{Description of selected plant remains}

Diversity of the charred plant remains was considerable and some specimens remained undetermined (Table 1 and S1). In the material, several taxa growing in natural or semi-natural habitats were recognized including forest mantles and grasslands as well as water plants. The plants are assigned to broad ecological groups (Ellenberg et al. 1991; Kreuz and Schäfer 2002, 2011; Mueller-Bieniek and Woch 2012) including water, water margins, boggy places (e1), grasslands, meadows, pastures (e2), ruderals/segetals unspecified (e4), cultivated (e5), weeds of root-crop plants and gardens (spring weeds) (e6), forests (e8), and various and unspecified (e9). No typical ruderals (e3) and weeds of autumn-sown field crops (winter weeds) (e7) were noted. Nevertheless, it must be underlined that the separation of plants into certain groups is based on modern botanical data and most of the synanthropic plants can have a broad ecological amplitude. They grow, at least occasionally, in different environmental conditions than those given in Table 1 (compare MuellerBieniek and Woch 2012). The anthropogenic plant communities are very unstable, created by humans and strongly influenced by human activity and evolving together with humans. Those plant communities include both local (apophyte) and alien (anthropophyte) plants and are very dynamic and dependent on local human activity and the appearance of new plant taxa, sometimes strongly competitive, and of invasive character (Matuszkiewicz 2001). Additionally, the origin of plants in an archeological sample is usually dubious as broadly discussed by Amy Bogaard during the selection of archeobotanical assemblages for a study of Neolithic crop husbandry practices (2004). Thus, the information obtained from modern ecological preferences of the plants found in archeobotanical samples is not "zero-one" but can give only some broad, general picture of past environment and husbandry practices as well as some trends. Plants of which fruits and seeds are mostly found in archeobotanical assemblages grow in open, not shaded habitats. But "open habitat" is not equivalent to "anthropogenic habitat" because there are several natural unforested habitats like for example screes, river banks, lake shores, xerothermic grasslands, and forest natural clearings. The most important difference in plant ecological groups is visible between those coming from fields (synanthropic communities, Stellarietea mediae, former Secalino-Violetalia: here as groups e4, e5, and e6) as strongly disturbed habitats and others from which the most distinctive in that context are plants growing in grasslands, meadows, and pastures (group e2). Nowadays, the latter are usually more stable plant communities with larger numbers of perennial species than typical synanthropic communities (Matuszkiewicz 2001; Snowarski 2002; Kreuz and Schäfer 2011). The most significant seeds and fruits are described below in alphabetical order by family name and most of the finds are illustrated and ascribed to broad ecological groups (Figs. 3, 4, 5, 6). Some of the remains seem to have been unripe before charring.

- Astrantia major L. (Apiaceae) - Fruits are longitudinal ellipsoid with tapering ends, dorsiventrally flattened, ventral 
Table 1 List of the plant taxa, their ecological classification, and number of remains. Plant names follow Mirek et al. 2002

\begin{tabular}{|c|c|c|c|c|c|}
\hline Plant name & Type of remain & EK & Lower sample & Upper sample & Sum \\
\hline Cerealia indet. & $\mathrm{c}$ & e5 & & 134 & 134 \\
\hline cf. Hordeum vulgare (naked) & $\mathrm{c}$ & e5 & & 4 & 4 \\
\hline Hordeum vulgare (hulled) & $\mathrm{c}$ & e5 & 9 & & 9 \\
\hline Panicum miliaceum & $\mathrm{c}$ & e5 & 1454 & 616 & 2070 \\
\hline cf. Pisum sativum & $\mathrm{s} / \mathrm{f}$ & e5 & & 3 & 3 \\
\hline Triticum diccocum & $\mathrm{c}$ & e5 & & 5 & 5 \\
\hline Triticum diccocum & $\mathrm{sb}$ & e5 & 1 & 1 & 2 \\
\hline Triticum diccocum & $\mathrm{gb}$ & e5 & 5 & 7 & 12 \\
\hline Triticum monоссосит & $\mathrm{c}$ & e5 & 1 & 3 & 4 \\
\hline Triticum mопососсит & $\mathrm{sb}$ & e5 & 1 & 8 & 9 \\
\hline Triticum sp. & $\mathrm{c}$ & e5 & 1 & 325 & 326 \\
\hline Triticum sp. hulled & $\mathrm{sb}$ & e5 & 6 & 20 & 26 \\
\hline Triticum sp. hulled & $\mathrm{gb}$ & e5 & 29 & 170 & 199 \\
\hline Triticum spelta & $\mathrm{c}$ & e5 & & 2 & 2 \\
\hline Triticum spelta & $\mathrm{sb}$ & e5 & 1 & & 1 \\
\hline Triticum spelta & $\mathrm{gb}$ & e5 & 3 & 7 & 10 \\
\hline cf. Agrimonia eupatoria & $\mathrm{s} / \mathrm{f}$ & $\mathrm{e} 2$ & 1 & & 1 \\
\hline Astragalus cicer/glycyphyllos & $\mathrm{s} / \mathrm{f}$ & e2 & 7 & 2 & 9 \\
\hline Astrantia major & $\mathrm{s} / \mathrm{f}$ & e8 & 4 & & 4 \\
\hline Avena sp. & $\mathrm{c}$ & e9 & 2 & 2 & 4 \\
\hline Bromus sp. & $\mathrm{c}$ & e9 & 1 & 8 & 9 \\
\hline Carex sp. & $\mathrm{s} / \mathrm{f}$ & e9 & 4 & 1 & 5 \\
\hline Chenopodium album type & $\mathrm{s} / \mathrm{f}$ & e4 & 453 & 302 & 755 \\
\hline Coronilla varia & $\mathrm{s} / \mathrm{f}$ & e2 & 11 & 2 & 13 \\
\hline Crepis sp. type & $\mathrm{s} / \mathrm{f}$ & e9 & 4 & & 4 \\
\hline Cuscuta sp. & $\mathrm{s} / \mathrm{f}$ & e9 & 1 & & 1 \\
\hline Digitaria ischaemum & $\mathrm{c}$ & e6 & 3 & & 3 \\
\hline Digitaria sp. & $\mathrm{c}$ & e4 & 115 & 173 & 288 \\
\hline Echinochloa crus-galli & $\mathrm{c}$ & e4 & 80 & 71 & 151 \\
\hline Elatine cf. hexandra & $\mathrm{s} / \mathrm{f}$ & e1 & 1 & & 1 \\
\hline cf. Euphrasia/Odontites & $\mathrm{s} / \mathrm{f}$ & e2 & 4 & & 4 \\
\hline Fallopia convulvulus & $\mathrm{s} / \mathrm{f}$ & e4 & 23 & 7 & 30 \\
\hline Festuca cf. pratensis & $\mathrm{c}$ & e2 & 2 & 4 & 6 \\
\hline Fragaria/Potentilla & $\mathrm{s} / \mathrm{f}$ & e9 & 3 & & 3 \\
\hline Galeopsis tetrahit type & $\mathrm{s} / \mathrm{f}$ & e4 & 1 & 1 & 2 \\
\hline Galium aparine & $\mathrm{s} / \mathrm{f}$ & e4 & 2 & 1 & 3 \\
\hline Galium sp. (small) & $\mathrm{s} / \mathrm{f}$ & e9 & 3 & & 3 \\
\hline Hypericum maculatum/montanum/tetrapteum & $\mathrm{s} / \mathrm{f}$ & e2 & 2 & & 2 \\
\hline cf. Juncus sp. & $\mathrm{s} / \mathrm{f}$ & e2 & 4 & & 4 \\
\hline Linum catharticum & $\mathrm{s} / \mathrm{f}$ & $\mathrm{e} 2$ & 2 & & 2 \\
\hline Luzula sp. & $s / f$ & e9 & 2 & 1 & 3 \\
\hline Malus silvestris & $\mathrm{s} / \mathrm{f}$ & e8 & 1 & & 1 \\
\hline Malva sp. & $\mathrm{s} / \mathrm{f}$ & e4 & 1 & & 1 \\
\hline Medicago lupulina & $\mathrm{s} / \mathrm{f}$ & $\mathrm{e} 2$ & 9 & & 9 \\
\hline cf. Medicago lupulina & $\mathrm{s} / \mathrm{f}$ & e2 & 14 & & 14 \\
\hline Melandrium cf. album & $\mathrm{s} / \mathrm{f}$ & e4 & 1 & & 1 \\
\hline Myosotis sp. & $\mathrm{s} / \mathrm{f}$ & e9 & 1 & & 1 \\
\hline cf. Myosoton aquaticum & $\mathrm{s} / \mathrm{f}$ & e1 & 2 & & 2 \\
\hline Origanum vulgare & $\mathrm{s} / \mathrm{f}$ & e2 & 1 & & 1 \\
\hline
\end{tabular}


Table 1 (continued)

\begin{tabular}{|c|c|c|c|c|c|}
\hline Plant name & Type of remain & EK & Lower sample & Upper sample & Sum \\
\hline cf. Pimpinella saxifraga & $\mathrm{s} / \mathrm{f}$ & e2 & 3 & & 3 \\
\hline Phleum/Poa & $\mathrm{c}$ & e2 & 25 & & 25 \\
\hline Plantago lanceolata & $s / f$ & e2 & 15 & 12 & 27 \\
\hline Plantago major/media & $s / f$ & e2 & 6 & 12 & 18 \\
\hline Polygonum aviculare i cf. & $\mathrm{s} / \mathrm{f}$ & e2 & 6 & 2 & 8 \\
\hline Polygonum persicaria type & $\mathrm{s} / \mathrm{f}$ & e4 & 150 & 97 & 247 \\
\hline Polygonum sp. (seeds) & $\mathrm{s} / \mathrm{f}$ & e4 & 52 & 81 & 133 \\
\hline Prunella vulgaris & $s / f$ & e2 & 8 & 1 & 9 \\
\hline Quercus sp. (hilum) & $\mathrm{s} / \mathrm{f}$ & e8 & 25 & 4 & 29 \\
\hline Quercus sp. (seed fragments) & $\mathrm{s} / \mathrm{f}$ & e8 & $\mathrm{xx}$ & $\mathrm{x}$ & $\mathrm{xx}$ \\
\hline Ranunculus sp. & $s / f$ & e9 & 3 & & 3 \\
\hline Rhinantus sp. & $s / f$ & e2 & 2 & 2 & 4 \\
\hline Rumex acetosa & $\mathrm{s} / \mathrm{f}$ & e2 & 3 & & 3 \\
\hline Rumex acetosella & $\mathrm{s} / \mathrm{f}$ & e2 & 6 & 5 & 11 \\
\hline Rumex sp. & $\mathrm{s} / \mathrm{f}$ & e9 & 1 & 1 & 2 \\
\hline Sambucus sp. & $\mathrm{s} / \mathrm{f}$ & e8 & & 1 & 1 \\
\hline Scleranthus annus/perennis & $\mathrm{s} / \mathrm{f}$ & e2 & 1 & 2 & 3 \\
\hline Stellaria graminea & $\mathrm{s} / \mathrm{f}$ & e2 & 22 & 3 & 25 \\
\hline Stellaria cf. uliginosa & $\mathrm{s} / \mathrm{f}$ & e1 & 6 & & 6 \\
\hline Stellaria sp./Myosoton aquaticum & $\mathrm{s} / \mathrm{f}$ & e9 & 8 & & 8 \\
\hline Trifolium cf. pratense & $\mathrm{s} / \mathrm{f}$ & e2 & 1 & & 1 \\
\hline Verbascum sp. & $\mathrm{s} / \mathrm{f}$ & $\mathrm{e} 2$ & 1 & & 1 \\
\hline Verbena officinalis & $\mathrm{s} / \mathrm{f}$ & e2 & 1 & & 1 \\
\hline Veronica sp. & $\mathrm{s} / \mathrm{f}$ & e9 & 18 & 3 & 21 \\
\hline Alliaceae/Liliaceae & $\mathrm{s} / \mathrm{f}$ & e9 & 1 & & 1 \\
\hline Apiace indet. & $\mathrm{s} / \mathrm{f}$ & e9 & 2 & & 2 \\
\hline Asteraceae indet. & $\mathrm{s} / \mathrm{f}$ & e9 & 2 & 2 & 4 \\
\hline Caryophyllaceae indet. & $\mathrm{s} / \mathrm{f}$ & e9 & 40 & 7 & 47 \\
\hline Chenopodiaceae indet. & $\mathrm{s} / \mathrm{f}$ & e9 & 3 & 3 & 6 \\
\hline Fabaceae indet. & $\mathrm{s} / \mathrm{f}$ & e9 & 45 & 22 & 67 \\
\hline Lamiaceae cf. Mentha & $\mathrm{s} / \mathrm{f}$ & e9 & 1 & & 1 \\
\hline Lamiaceae indet. & $\mathrm{s} / \mathrm{f}$ & e9 & 3 & 2 & 5 \\
\hline Panicoidae & $\mathrm{c}$ & e4 & 12 & 80 & 92 \\
\hline Poaceae indet. (large) & $\mathrm{c}$ & e2 & 7 & 1 & 8 \\
\hline Poaceae indet. (small) & $\mathrm{c}$ & e2 & 336 & 211 & 547 \\
\hline Trifoliae & $\mathrm{s} / \mathrm{f}$ & e2 & 2 & 5 & 7 \\
\hline Cyperaceae indet. & $\mathrm{s} / \mathrm{f}$ & e9 & 1 & & 1 \\
\hline
\end{tabular}

$s b$ spikelet bases, $g b$ glume bases, $c$ caryopsis, grain, $s / f$ seed/fruit, EK: ecological group, $e 1$ water, water margins, boggy places, $e 2$ grasslands, meadows, pastures, $e 4$ ruderals/segetals unspecified, $e 5$ cultivated, $e 6$ weeds of root-crop plants and gardens (spring weeds), $e 8$ forests, $e 9$ various and unspecified; $x x$ numerous, $x$ some

side flat, and dorsal convex. On the dorsal side, five thick ribs with serrated, jagged surface built up from connate scales (Anderberg 1994, p. 106), after charring, forming characteristic rough nodulous sculpture (Fig. 5a). Surface between ribs (valleculae) is narrow. On the ventral side, two resin canals (vittae) are not visible in the charred material. Charred remains from Lipnik are relatively small when compared with modern, rather massive specimens.
Though they are very damaged, their shape, size, and very characteristic surface allowed certain identification. Size $=$ ca. $4.8 \times 1.5,4.7 \times 1.7$, and $3 \times 1.3 \mathrm{~mm}$

- cf. Pimpinella saxifraga L. (Apiaceae) - One specimen small $(1.7 \times 0.9 \mathrm{~mm})$ reniform, convex on the dorsal side with visible remains of ribs. The ventral side is slightly convex due the high temperature causing carbonization but the central groove is still visible. The second specimen 

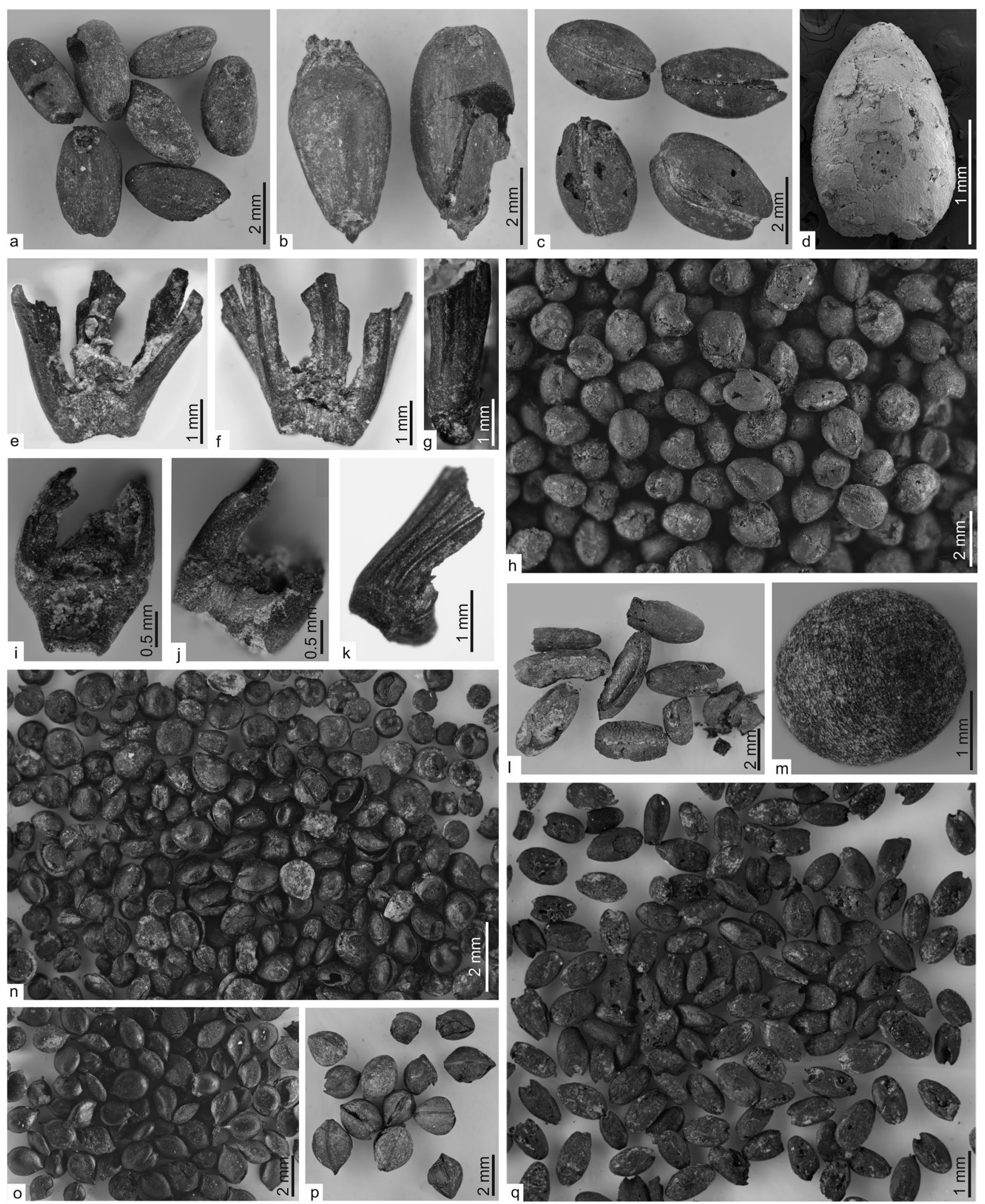

is oval, bigger $(2.0 \times 1.1 \mathrm{~mm})$, slightly dorsiventrally flattened, with visible ribs and stripes between them. In the upper part of both specimens, the remains of the

stylopodium are visible. The small size, shape, and surface are similar to $P$. saxifraga. Modern seeds of $P$. saxifraga are dorsiventrally flattened, concave or flattened on the 
Fig. 3 The Middle Bronze Age, charred plant macro-remains from the Lipnik site, cultivated and synanthropic plants. a Grains of emmer/spelt (Triticum dicoccum/spelta). b Grains of $T$. cf. spelta. c Grains of barley (Hordeum vulgare). d Grain of proso millet (Panicum miliaceum) with visible remains of lemma. e-g Spikelet base of emmer (Triticum cf. dicoccum) from ventral, dorsal, and lateral view. $\mathbf{h}$ Grains of proso millet (Panicum miliaceum). i-j Spikelet base of einkorn (Triticum monococcum). $\mathbf{k}$ Glume base of spelt (Triticum spelta). 1 Grains of Bromus sp.. m Seed of Galium aparine with clearly visible characteristic sculpture. $\mathbf{n}$ Seeds of Chenopodium album type, in that broad group other species from that genera are possibly included. o Nutlets of Polygonum persicaria. p Nutlets of Fallopia convolvulus. q Grains of Digitaria sp.. In the material, a few glumed grains of $D$. ischaemum were noted (photos M. Kapcia, M. Szewczyk) ventral side, and the dorsal side is convex with five narrow ribs (Anderberg 1994). Taking into account the generally smaller size of charred, ancient remains compared to their modern analogs as well as the relatively delicate morphological features of fruits from the Apiaceae family, usually strongly affected by charring, other species from the genus Pimpinella and other genera from the Apiaceae family producing similar fruits, cannot be excluded.

- Crepis L. type (Asteraceae) - Specimens are oblong, spindle form, with narrow beaks at the ends; slightly flattened at one end. Surface covered with tiny ribs (Fig. 5k). Similar to genus Crepis in shape and sculpture. Species from genera
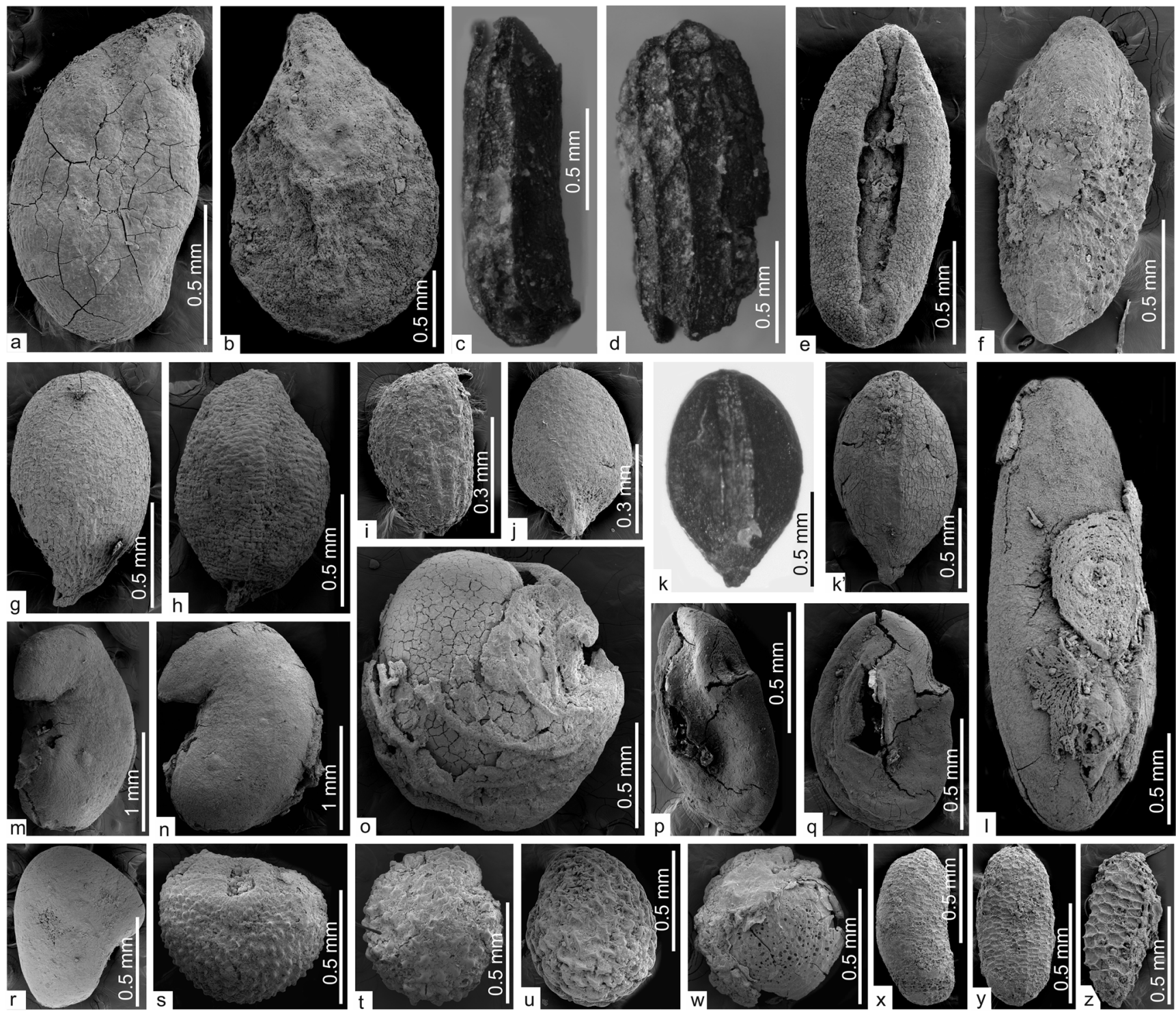

Fig. 4 The Middle Bronze Age, charred plant macro-remains from the Lipnik site, growing in meadows, grasslands, forest mantles, and water shores. a Linum catharticum. b Rhinanthus cf. serotinus. c-d Verbena officinalis. e Plantago lanceolata. f Plantago major. g Phleum pretense. h Luzula sp.. i Juncus sp.. j Origanum vulgare. k Prunella vulgaris. I Coronilla varia. m-n Astragalus cicer/

glacyphyllos. o Medicago lupulina with visible legume remnants. $\mathbf{p}-\mathbf{q}$ cf. Medicago lupulina, probably unripe seeds. $\mathbf{r}$ Trifolium $\mathrm{cf}$. pratense. s Melandrium cf. album. t cf. Myosoton aquaticum. u Stellaria graminea. w Stellaria sp./Myosoton aquaticum. $\mathbf{x}-\mathbf{y}$ Hypericum maculatum/montanum/tetrapterum. $\mathbf{z}$ Elatine $\mathrm{cf}$. hexandra (photos M. Kapcia) 

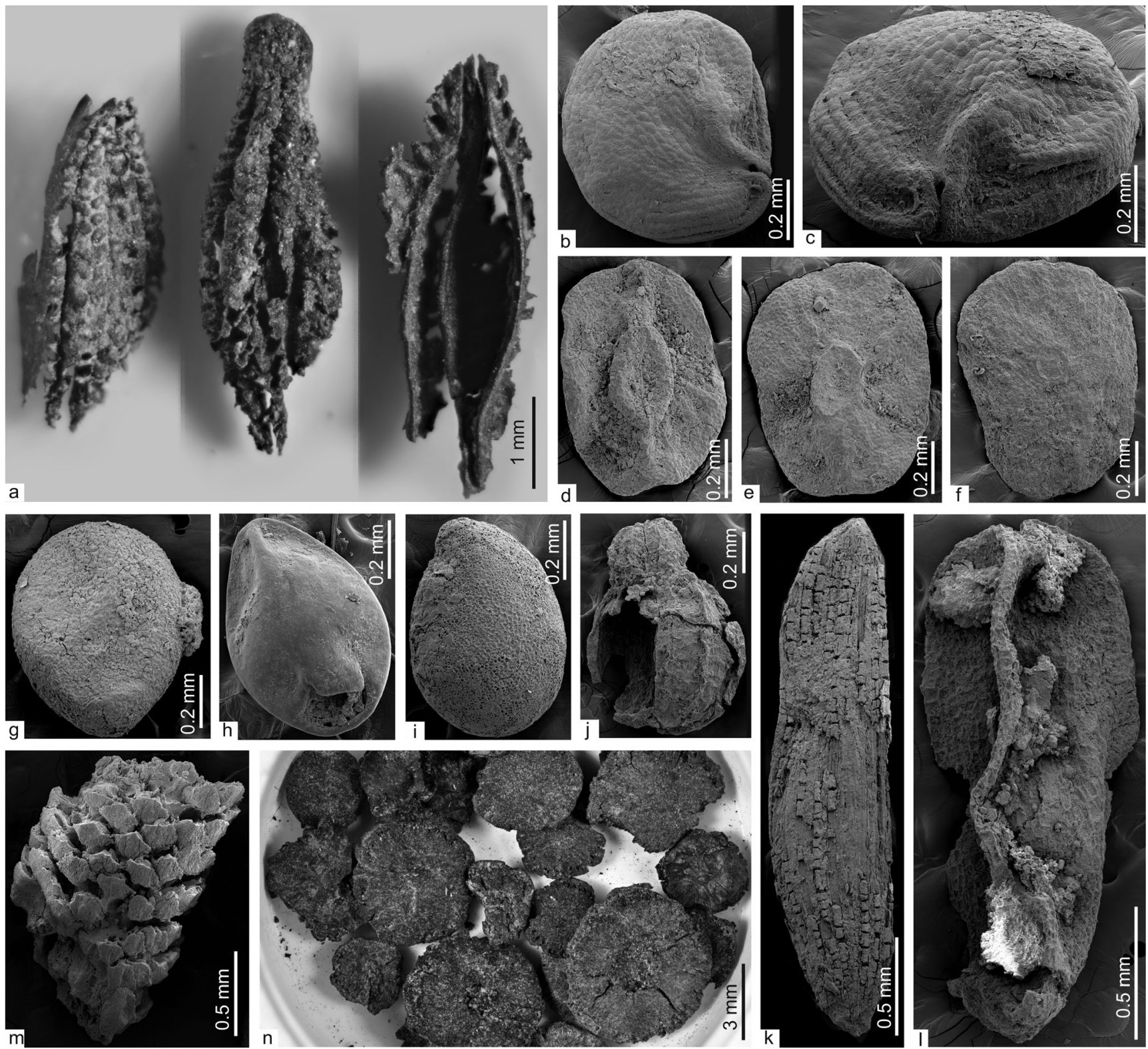

Fig. 5 The Middle Bronze Age, charred plant macro-remains from the Lipnik site, from diverse ecological groups including forests and forest mantles. a Astrantia major. b Chenopodiaceae indet. (cf. Atriplex prostrata/Chenopodium urbicum). d-f Different species of Veronica. $\mathbf{f}$

Veronica cf. scutellata. g Cuscuta sp.. h Myosotis cf. arvensis. i indet.. j Apiaceae indet.. k Asteraceae Crepis type. I Alliaceae indet./Liliaceae indet.. m indet.. n Quercus sp. acorn hila (photos M. Kapcia, M. Szewczyk)

Tragopogon, Scorzonera, and Leontodon also have similar fruits. The specimens are relatively small $(2.6 \times 0.6 ; 3.15 \times$ $0.6 ;>2.5 \times 0.55 ;>2.5 \times 0.75 \mathrm{~mm}$ ) but the smaller size of charred ancient remains is a common factor.

- Myosotis cf. arvensis (L.) Hill (Boraginaceae) - Nutlet ovoid, dorsiventrally flattened, slightly convex on both sides (Fig. 5h). Apex blunt and strongly dorsiventrally flattened. On the ventral side from the apex to approx. one fourth of the length of the specimen a rib is visible, before charring it was most probably strongly rooflike. On the ventral side, at the rounded base, a relatively large hilum is visible, partly destroyed by charring and soil processes.
Distinct lateral grooves typical of many Myosotis species are not visible but their absence can be caused by swelling connected with charring. Size $=0.77 \times 0.5 \mathrm{~mm}$

- Melandrium cf. album (Mill.) Garcke (Caryophyllaceae) Almost circular seed, concave around the hilum, with convex lateral sides and marginal, dorsal face. No distinct edges between lateral and marginal sides are visible but that character could be lost due to charring (Fig. 4s). Modern, uncharred seeds can be reniform or circular (Bojnanský and Fargašová 2007). Surface covered with dense pattern of rather chaotically arranged papillae, on marginal side, in more regular rows. Around a cavity on ventral side, where 

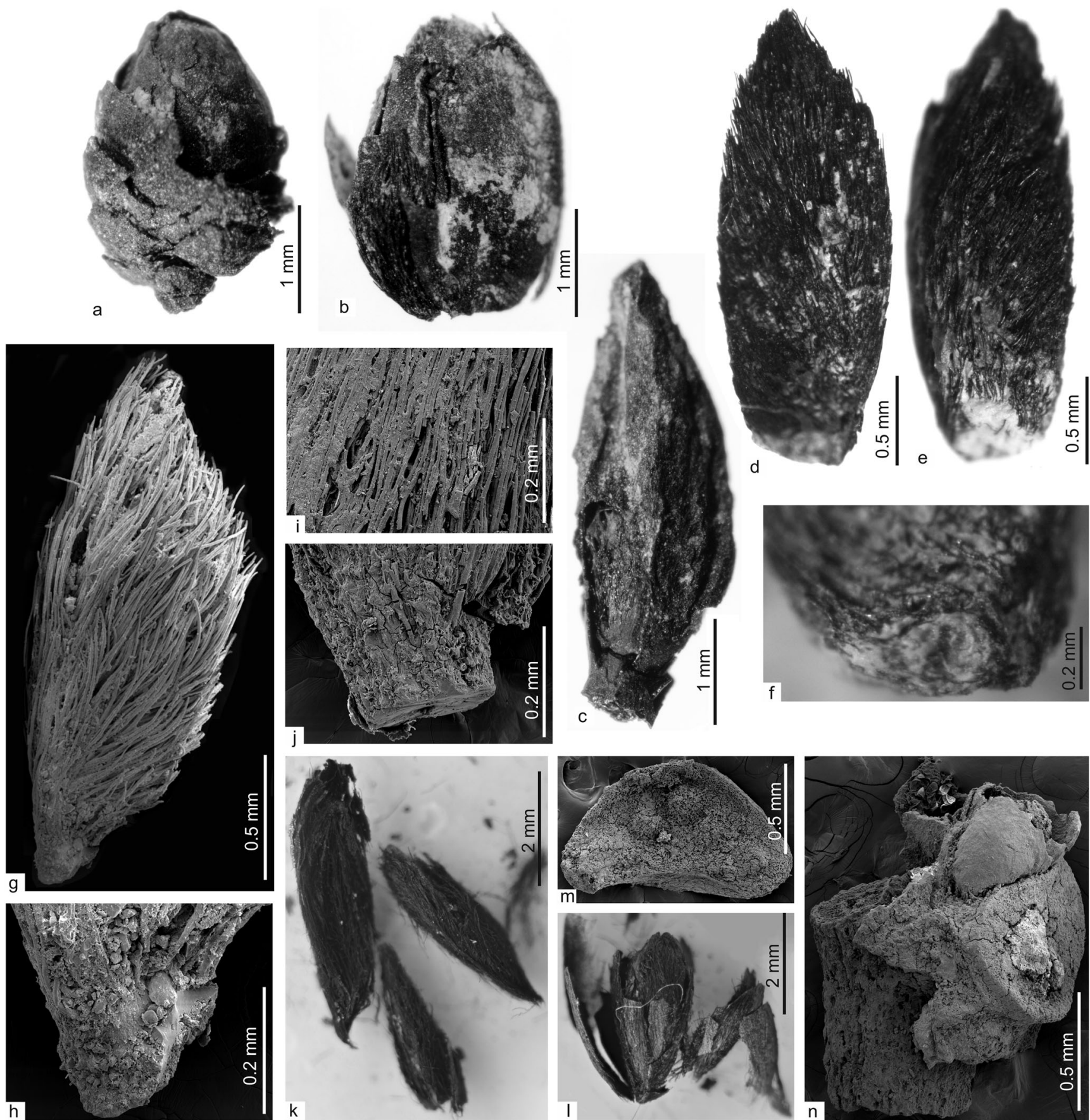

Fig. 6 Charred Middle Bronze Age tree buds from the Lipnik site (a-j). $\mathbf{a}-\mathbf{b}$ Quercus sp.; $\mathbf{m}-\mathbf{n}$ twig terminal parts and leaf scars from the Lipnik site; $\mathbf{k}-\mathbf{I}$ charred recent winter buds of Sorbus aucuparia (k) and Quercus robur (l) (photos M. Kapcia, A. Mueller-Bieniek)

the hilum is located, a surrounding callus is visible. The shape, surface pattern, and size is similar to M. noctiflorum, but the fold (callus) surrounding the hilum is typical of M. album (Kulpa 1974; Berggren 1981). The specimen from the Lipnik site is slightly smaller than the modern seeds from the comparative reference collection. Size $=0.8 \times 0.65 \mathrm{~mm}$.

- cf. Myosoton aquaticum (L.) Moench (Caryophyllaceae) The seeds are broadly elliptic or roundish in outline, laterally flattened, and slightly convex on both sides. Surface covered mainly by stelliform papillae, blunt at the end, and adjacent to each other (Fig. 4t). On the marginal, side papillae are more oblong, but usually not creating clear wrinkles arranged in rows, some more regular lines are visible on the radicle end. Specimens similar to M. aquaticum, such as Stellaria nemorum cannot be excluded with certainty. Size $=0.8 \times 0.7$ and $0.8 \times 0.8 \mathrm{~mm}$.

- Scleranthus annuus L. (Caryophyllaceae) - Pseudocarps in shape of tulip, tapering to the base, and on the surface, 
10 thick ribs are visible. In one specimen, preserved sepals are typical for $S$. annuus; in two other specimens, sepals are destroyed which make precise identifications impossible but we can suppose that they also belong to the same species. Size: one specimen with sepals $2.4 \times 1.1$, without sepals $1.5 \times 1.0$ and $1.4 \times 1.05 \mathrm{~mm}$

- Stellaria graminea L. (Caryophyllaceae) - Seeds are elliptic in shape and laterally flattened. Surface covered by elongate, undulate papillae, creating circular lines (Fig. 4u). Seeds with similar wrinkles include $S$. palustris and $S$. alsine but they differ in size and wrinkle pattern (Berggren 1981). Size $=$ $0.75 \times 0.65,0.8 \times 0.65,0.65 \times 0.55,0.6 \times 0.5,0.7 \times 0.55$, $0.8 \times 0.7,0.7 \times 0.6,0.7 \times 0.6$, and $0.7 \times 0.6 \mathrm{~mm}$.

- Stellaria cf. uliginosa Murray (Caryophyllaceae) - Seeds elliptic in shape or roundish, laterally flattened, similar to $S$. graminea but papillae are stelliform and more distinct. Size $=0.65 \times 0.55,0.65 \times 0.6,0.65 \times 0.6$, and $0.65 \times 0.65 \mathrm{~mm}$.

- Stellaria sp./M. aquaticum (Caryophyllaceae) - Roundish seeds, with damaged surface (testa) but with characteristic papillae reflection visible (Fig. 4w). Most of them probably belong to $S$. graminea.

- Cuscuta sp. L. (Cuscutaceae) - Seed is obovoid, dorsal side convex, ventral rooflike, with asymmetric depressions (Fig. 5g). In the slightly narrowed base, on the ventral side, there is a diagonal cut where the hilum should be visible. Surface is rugged. Seeds are not distinguishable on the basis of their morphology (Kulpa 1974). In the geographical and historical context, C. europaea, C. epithymum, and C. epilinum are possible; the latter is known as a specialized flax weed and is extinct now. Size $=0.83 \times 0.66 \mathrm{~mm}$.

- Elatine cf. hexandra (LAPIERRE) DC. (Elatinaceae) Seed narrowly obovate in outline, slightly curved. Surface covered with a reticulate pattern of large transversally elongated cells arranged in rows, ca. 12-13 cells in one row (Fig. 4z). The size of the seed from Lipnik is $0.8 \times$ $0.3 \mathrm{~mm}$. The seed was compared with specimens from the genus Hypericum. Modern seeds of $H$. perforatum and $H$. humifusum have the same coarse reticulate pattern. $H$. perforatum has seeds narrowly elliptic or elliptic, sometimes slightly curved and longer $(0.8-1.3 \times 0.3-0.4 \mathrm{~mm})$ than $H$. humifusum $(0.5-0.7 \times 0.3-0.4 \mathrm{~mm})$, which has elliptic and straight seeds. The ancient specimen has coarser reticulate pattern in relation to its size than specimens of Hypericum from the reference collection. The seed shapenarrowing to the lower end and rounded on the apex with a small beak in its center - and reticulate surface also resembles the genus Elatine. There are four species of Elatine in the Polish flora (E. alsinastrum L., E. hexandra (LAPIERRE) DC., E. hydropiper L. em. OEDER, E. triandra SCHKUHR). All are rare and endangered and none of their seeds are accessible in the modern reference collection. Seeds of $E$. alsinastrum have a reticulate surface with more than 20 cells in every row (Katz et al. 1965) and the size of Pleistocene seeds of E. alsinastrum is given as $0.4-0.5 \times 0.15-0.2 \mathrm{~mm}$, while modern seeds are larger (length 0.6-0.8, up to $1 \mathrm{~mm}$ ) (Katz et al. 1965; Velichkevich and Zastawniak 2008). E. hexandra seeds have a similar size (length $0.5-0.8 \mathrm{~mm}$ ) but much a coarser reticulate pattern (Katz et al. 1965). The seed from the Lipnik site was compared with waterlogged specimens from a Pleistocene reference collection identified by $\mathrm{F}$. Velichkevich and stored in the W. Szafer Institute of Botany PAS (number of collection Q-337). In that collection, specimens identified as E. alsinastrum and E. tiandra are preserved (Velichkevich and Zastawniak 2008). According to the literature, the most probable is E. hexandra (Katz et al. 1965) as seeds of E. hydropiper have a different shape and seeds of E. alsinanstrum and E. triandra have a more delicate reticulate pattern. All species of Elatine grow in very wet soil or in water, generally in habitats with fluctuating water levels. The detailed description of N. European species of Elatine and their Holocene occurrence in relation to climatic fluctuations was broadly discussed by Brinkkemper et al. (2008).

- Astragalus cicer L./glycyphyllos L. (Fabaceae) - Reniform seeds are laterally flattened, testa usually lacking (Fig. 4mn). Radicle ca. one half or less of the seed length, obtuse. Size $=2.2 \times 1.7,2.0 \times 1.6 .2 .1 \times 1.6,2.0 \times 1.5,2.0 \times 1.6$, $2.1 \times 1.7,2.3 \times 1.5$, and $2.0 \times 1.4 \mathrm{~mm}$. Both species grow in similar habitats (open forests and their edges, thickets, grasslands, in general ecotones between forests, and open lands); other species are excluded because of their recent occurrence (high mountains, xerothermic grasslands).

- Coronilla varia L. (Fabaceae) - Seeds are oblong, sides are slightly flattened but in charred material usually circular in cross-section, and ends are rounded. Surface is smooth, but in charred specimens, the testa is usually lacking. Halfway down the length of the ventral side, a large rounded hilum is still preserved in some specimens (Fig. 4l). Size $=2.4 \times 0.9$, $2.2 \times 0.7,2.15 \times 0.7,1.6 \times 0.6,2.35 \times 0.9,1.7 \times 0.9,2.55 \times$ $0.95,1.85 \times 0.85,2.6 \times 1.0,1.65 \times 0.65$, and $1.6 \times 0.6 \mathrm{~mm}$.

- Medicago lupulina L. (Fabaceae) - One seed preserved with remnants of a one-seeded pod with very characteristic ribs (Fig. $4 \mathrm{o}$, ca. $1.4 \times 1.25 \mathrm{~mm}$ ). Some seeds still have small fragments of the seed pod $($ size $=1.4 \times 0.9,1.5 \times 1.3$, and $1.5 \times 1.0 \mathrm{~mm}$ ). Seeds are ellipsoid, laterally flattened radicle ca. two thirds of seed's length, divergent at the end forming a small beak (Anderberg 1994), testa usually preserved. On the lateral side, close to the margin, a distinct furrow is visible (Fig. 4p, q). Size $=1.0 \times 0.6,1.35 \times 0.9,1.3 \times 0.85$, $1.4 \times 0.9,1.1 \times 0.7,1.4 \times 0.9,1.3 \times 0.8$, and $1.2 \times 0.75 \mathrm{~mm}$. Recent seeds are generally larger $(1.4-2.3 \times 1.1-1.5 \times 0.9-$ $1.1 \mathrm{~mm}$ ), not so flattened, with smooth, convex sides. The ancient seeds were probably not ripe before charring, and they most probably also belong to $M$. lupulina. 
- Trifolium cf. pratense L. (Fabaceae) - The taxonomical keys mostly use color of seeds to separate them to species level (Anderberg 1994), a characteristic lost in charred material. The size and shape of the ancient seed is typical for Trifolium. It is heart-shaped. The sides are convex and marginal side is rounded. Radicle reaching one half of the seed length is divergent. Hilum in the middle, located in a hollow near the end of radicle. The shape is most similar to T. pretense (Fig. 4r). The ancient seed is smaller than recent ones but there are no morphological signs of unripeness. Size $=0.9 \times 0.7 \mathrm{~mm}$.

- Luzula sp. (Juncaceae) - Seeds elliptical, ventral side slightly convex, with a visible ridge running from top to bottom, on the lower end visible characteristic beak, apex rounded, surface rugged (Fig. 4h). Surface, size, and shape are most similar to L. luzuloides but because of charring and suspected unripe condition, L. multiflora and other species cannot be excluded with certainty. Size $=1.0 \times$ $0.6,0.9 \times 0.55$, and $0.9 \times 0.55 \mathrm{~mm}$.

- Prunella vulgaris L. (Lamiaceae) - Mericarps are almost elliptic, diamond-shaped (Fig. 4k). Modern fruitlets are usually obovate. That change in outline could be caused by charring which mostly affected the apex part. Dorsal side slightly convex, ventral slightly rooflike. On both sides and margins wide, longitudinal furrows are visible. At the base, an attachment is still present forming a beak. Surface is smooth. Size $=1.4 \times 0.85,1.2 \times 0.75,1.3 \times 0.9$, $1.25 \times 0.9,1.2 \times 0.9,1.25 \times 0.8$, and $1.15 \times 0.7 \mathrm{~mm}$.

- Origanum vulgare L. (Lamiaceae) - Mericarp is ovate, slightly dorsiventrally flattened, broadest below its center, tapering sharply to the lower end, forming a distinct beak with a short distinctive rib (Fig. 4j). The specimen from the Lipnik site is much smaller than specimens from the reference collection. Size $=0.55 \times 0.4 \mathrm{~mm}$.

- Linum catharticum L. (Linaceae) - Seeds are crescent-like, asymmetric obovate in outline, laterally flattened, one side almost flat, the other side slightly convex and asymmetric in cross-section. On the surface, fine reticulate pattern is visible, especially at marginal parts of the seed (Fig. 4a). Size $=1.0 \times 0.6$ and $1.05 \times 0.6 \mathrm{~mm}$.

- Polygonum persicaria L. (Polygonaceae) - Nutlets are ovate or broadly ovate and dorsiventrally flattened (Fig. 3o). In many specimens, one side is less convex than the other. In the lower part, a scar attachment is visible, the upper part gradually narrowed to the point. Very numerous in the assemblage. Several specimens with a partly or totally lacking outer layer most probably belong to that species (as $P$. sp. (seeds) in Table 1 ). Size $=1.5 \times 1.1$, $1.8 \times 1.0,1.6 \times 1.2,1.9 \times 1.2,1.8 \times 1.25,1.5 \times 1.0,1.7 \times$ $1.1,1.5 \times 1.1,1.75 \times 1.4$, and $1.75 \times 1.15 \mathrm{~mm}$.

- Galium aparine L. (Rubiaceae) - Fruit achenes spherical, slightly flattened on the ventral side, and concave in the middle. The surface of modern specimens are densely covered with hooked spines. In the charred form, the outer layer with hooks is not preserved (Fig. 3m). Surface is rough and covered with reticulate pattern of elongated cells arranged in rows. Size $=2.1 \times 1.9,2.2 \times 2.0$, and $1.7 \times 1.8 \mathrm{~mm}$.

- Rhinanthus cf. serotinus Schonh. (Scrophulariaceae) - Seeds are ovate, apex almost triangular, laterally flattened, with sharp margins, slightly convex in the middle of the seed (Fig. 4b). On the surface, wrinkles and delicate reticulate pattern are visible. No wings are visible. Modern, uncharred seeds usually have membranous wings, some weedy forms have reduced or no wings which is their adaptation for spreading with the seed corn (Jasiewicz 1963; Kulpa 1974; Mizianty 1978). From an archeobotanical perspective and the history of weed-crop interrelations, information about the ecological type of the plant is very important. Seeds of several recent taxa and varieties taken from the herbarium of the W. Szafer Institute of Botany were studied, including their artificial charring. The taxonomy of the genus is extremely difficult and several subspecies of Rhinanthus serotinus and $R$. alectorolophus were studied. Charring usually destroys wings, they come off leaving a scar which is hardly visible in ancient specimens. Modern wingless seeds have no marginal rib or scar after charring. Ancient remains have wavy, unsmooth margins, probably indicating the presence of wings before carbonization. Nevertheless, we cannot conclusively exclude the wingless weedy form and that subject needs more experimental studies and more samples from archeobotanical material. Size $=2.2 \times 1.4,2.0 \times 1.2,1.55 \times$ 1.0 , and $1.6 \times 0.9 \mathrm{~mm}$.

- Undetermined Alliaceae/Liliaceae - Seed \pm elliptic, destroyed at margins, seemingly unripe before charring, with a distinct, longitudinal ridge in the middle of probably ventral side (Fig. 51). The seed has a distinct reticulate pattern resembling those visible in some members of Alliaceae (Allium sp.) and Liliaceae (Gagea sp.) families. Size $=1.9 \times 0.85 \mathrm{~mm}$

- Chenopodiaceae indet. - One relatively small seed (less than $0.8 \mathrm{~mm}$ ) with very distinct surface pattern (sculpture) (Fig. 5b) resembling Atriplex prostrata BOUCHER ex DC. (= \pm Atriplex hastatum L.) and Chenopodium urbicum L.. A. prostrata has at least three subspecies in the Polish flora, and C. urbicum is not a native plant according to the Polish flora (Mirek et al. 2002). Other seeds from that group are found with destroyed testa and most probably belong to C. album type.

Several well-preserved seeds and fruits are still not identified (Fig. 5, Table 1). Most probably they do not belong to weedy and ruderal species as those groups of plants have been extensively studied archaeobotanically, documented in many papers and key-atlases, and are relatively easy to recognize. Several specimens are identified only to family level. Many tree buds were also noted. Most of them belong to Quercus sp. (Fig. 6a, b). The most interesting were hairy items previously 
suspected to be remains of zoological origin (Fig. 6). They also resemble inner parts of winter buds formed by dense hairs. Following Szymanowski (1974) two genera of trees were selected (Quercus sp. and Sorbus sp.) and their winter buds were collected and charred (Fig. 6k, 1). Ancient fragments are definitely fragments of winter buds but their exact identification to genus level is not possible.

\section{Results}

Most of the plant macro-remains are charred. In the material only a single uncharred specimen of $C$. album was found. Charred remains are usually smaller than their modern analogs. Some of the plant remains were most probably unripe before charring. Several specimens remained undetermined despite their relatively good preservation showing the extraordinary composition of the assemblage from an archeobotanical point of view. Ecological groups of plants are given after ARBODAT (Kreuz and Schäfer 2002; Pokorná et al. 2011; modified in Mueller-Bieniek and Woch 2012). Most of the taxa are documented and the findings are listed in Table 1, where results from the two subsamples of different depths are listed separately. The samples may slightly overlap the adjacent archeological layers. The lower sample contained more remains of acorns, clearly visible in the field, from where a monolith sample was taken (Fig. 2). In that sample, proso millet (also known as broomcorn millet or common millet, Panicum miliaceum) grains dominated in number and other crop remains were very scarce (Fig. 7). In contrast, the upper sample, apart from millet, also contained numerous remains of hulled wheats, including einkorn (Triticum monococcum), emmer (T. dicoccum), and spelt (T. spelta). Barley (Hordeum vulgare) grains were very scarce in both samples. A very limited number of probable peas (cf. Pisum sativum) with no hilum preserved, were noted only in the upper sample.

Besides cultivated plants and acorns, the material is strongly dominated by taxa of grassland plants, specimens of which were also very numerous, especially in the lower sample (e2, Figs 7 , 8). Ruderal plants and weeds (e4) are also very common in both samples, but represented by relatively small numbers of taxa (Fig. 8, C. album type, P. persicaria, Digitaria sp., Echinochloa crus-galli, Fallopia convolvulus, Galeopsis tetrahit, and Melandrium album). They all have rather resistant diaspores, usually well preserved in archeobotanical assemblages. Diaspores from Poaceae and Polygonaceae families as well as C. album are known as a source of food (Maurizio 1926; Helbaek 1958; Behre 2008). That fact, as well as the likely local origin of these synanthropic plants and their resistance to decay may explain their large quantities (Mueller-Bieniek and Walanus 2012; Colledge and Conolly 2014). Purposive collection of C. album, P. persicaria, Digitaria sp., E. crus-galli, as well as $F$. convolvulus as sources of edible seeds/fruits cannot be excluded but determining the exact source of those common weeds and ruderal plants in archeobotanical assemblages is usually not definitive (Kohler-Schneider 2001; Mueller-Bieniek and Walanus 2012; Mueller-Bieniek et al. 2015a). G. aparine, represented by a few specimens, is described in the archeobotanical database (ArboDat) as a ruderal plant (e3) but can also grow in other open habitats, including forest mantles and, in this paper, was included in the group e4. Verbena officinalis, an archeophyte with very characteristic diaspores was found only as one slightly damaged specimen, and in accordance with ArboDatMulti, is here assigned as a grassland plant, even though in the Polish data it is known mainly as a ruderal (Zając and Zając 2015) growing also on dry slopes and roadsides (Rutkowski 2008). In the lower sample, single (charred) remains of plants growing in very wet or aquatic conditions were also noted (Elatine cf. hexandra, cf. M. aquaticum, Stellaria cf. uliginosa). The division of plants into ecological groups is very broad and it should be taken into account that several plant taxa can grow in habitats other than those given in Table 1. Several grassland taxa found in the material can also grow in forest mantles. A limited number of examples of forest plants were also noted including A. major and diaspores of trees and shrubs (Quercus sp., Malus sp., and Sambucus sp.).

Three samples of grains from the Lipnik site were analyzed isotopically at the Institute of Archeology, University of Oxford (Table 2). The results of $\delta^{13} \mathrm{C}$ ratio are typical for $\mathrm{C} 3$ (emmer and spelt wheats) and $\mathrm{C} 4$ (proso millet) plants. $\delta^{13} \mathrm{C}$ for $\mathrm{C} 4$ plants range from -9 to $-14 \%$, whereas $\mathrm{C} 3$ plants range from -20 to $-35 \%$ o (Katzenberg 2008). The single samples do not permit reliable environmental interpretation of the data. Nevertheless, $\delta^{13} \mathrm{C}\left(\Delta^{13} \mathrm{C}\right)$ and $\delta^{15} \mathrm{~N}$ values of the wheats suggest a medium/high level of manuring (Bogaard et al. 2013; Fig. 1) and moderately watered plots (Wallace et al. 2013). On the other hand, the $\delta^{13} \mathrm{C}$ value of millet, close to the most positive values for $\mathrm{C} 4$ plants, suggests rather high stomatal resistance (O’Leary 1981) probably linked to limited water during the plants' growth. Those data need further studies including experimental ones. On the site, no bone remains were preserved due to soil conditions (Przybyła pers. comm.).

\section{Discussion}

At the time when the plant assemblage was deposited, the area was forested as has been detected by palynological analysis (Mamakowa and Wójcik 1999; Łańczot et al. 2003; Zernickaya et al. 2003; Kołaczek 2011). Human impact and agricultural practices are visible in indirect environmental data like changes in the increase of pollen curves of pioneer trees and grassland plants as well as in the intensification of slope processes (Klimek et al. 2006). It is also known that the upland area of loess was settled from the beginning of the Neolithic period (Przybyła and Blajer 2008; Przybyła pers. comm.). In the Lipnik site, soil samples were 


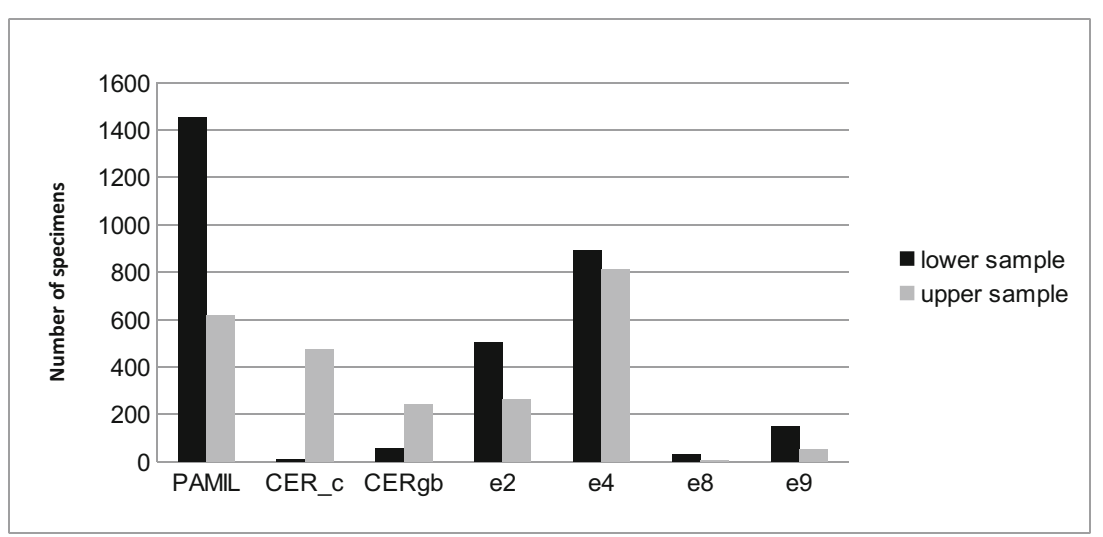

Fig. 7 Number of specimens belonging to broad ecological groups. Cultivated plants are divided into (1) proso millet (Panicum miliaceum) grains (PAMIL); (2) grains of cereals (hulled wheats including Triticum dicoccum, T. spelta, and T. monococcum; and barley Hordeum vulgare (CER_c); (3) chaff remains of hulled wheat, spikelet bases, and glume bases calculated to number of

also taken from other pits but they contained mostly wood charcoal remains and only single charred grains of proso millet. Despite the predominance of grassland species in the studied feature 302, diaspores of millet, hulled wheats, and synanthropic plants were the most numerous. Among them archeophytes from the subfamily Panicoidae (E. crus-galli and Digitaria sp.) were very important, probably coming from proso millet plots. It seems that there were at least two layers (or zones) within the pit reflecting diverse types of food. The first, from the lower sample, was dominated by acorn fragments (by volume), and proso millet grains as well as a diversity of grassland taxa and most of the forest and aquatic plants. In that layer almost no remains of "valuable" crops, like wheat, were found. The upper layer, probably reflecting subsequent activities or some other packet of stored food, also contained some acorns and millets but wheat become very numerous. Here, we cannot be sure if the subsequent layers were taken separately and some overlapping of the samples is possible. The finds of oak leaf buds, and of probable other trees, as well as several twig fragments are significant. Large amounts of oak buds were also noted in the Iron Age settlement of Groß Meckelsen in Lower Saxony, but their economic explanation is uncertain (Behre 2017). glume bases(CERgb). For other abbreviations, see Table 1. E8 group includes acorn remains calculated on the basis of preserved hila (Fig. 5n), which strongly dominated in terms of volume of fragmented cotyledons. The group of plants growing in aquatic and very wet habitats (e1) is omitted because of a very low number of specimens, found only in the lower sample

Proso millet has, until now, scarcely been observed in archeobotanical data from other sites dated to the Middle Bronze Age, especially the Trzciniec culture, from Poland (Wasylikowa et al. 2002; Moskal-del Hoyo et al. 2015). Neolithic evidence in central Europe is reported in archaeobotanical studies usually through limited remains of millet grains interpreted as weeds (compare Lityńska-Zając and Wasylikowa 2005; Zohary et al. 2012; Motuzaite-Matuzeviciute et al. 2013). Nevertheless, in the light of direct radiocarbon dating of supposed Neolithic grains of millet (Motuzaite-Matuzeviciute et al. 2013) as well as genetic studies of ancient and modern material (Li et al. 2016), their Neolithic European cultivation seems very uncertain. AMS radiocarbon dating of grains found in undisturbed Neolithic contexts of the sixth millennium BC, gave radiocarbon dates a few thousand years younger (Table 2 in Motuzaite-Matuzeviciute et al. 2013); the oldest was dated to the middle of the second millennium BC (Hungary, site Fajsz 18, archeologically attributed to the Sopot culture, AMS of millet grain: OxA-26,704, $3214 \pm 36{ }^{14} \mathrm{C}$, after calibration with $95.4 \%$ probability giving 1606-1414 cal. BC). In Slovakia (Hajnalová 2012), single proso millet grains were found in three Early Bronze Age sites (first half of second millennium BC). In the Late
Fig. 8 Number of taxa belonging to broad ecological groups. For abbreviations for ecological groups, see Table 1

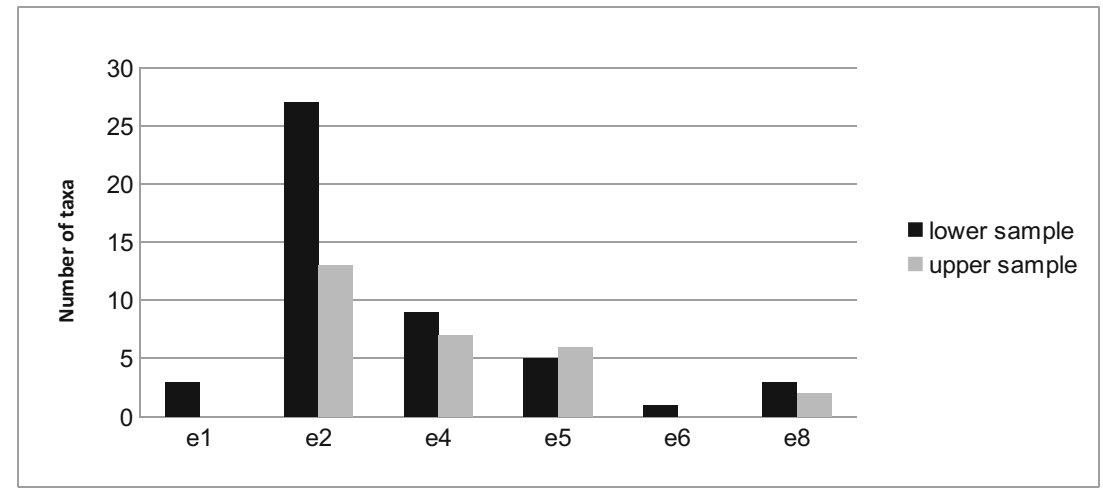


Table 2 Stable $\mathrm{N}$ and $\mathrm{C}$ isotopic composition in grains from the studied archeological feature 302 from the Lipnik site

\begin{tabular}{lllllllll}
\hline Plant & Latin name & $\begin{array}{l}\text { Number of } \\
\text { grains }\end{array}$ & $\mathrm{d} 13 \mathrm{C}$ & $\mathrm{d} 13 \mathrm{Csd}$ & $\mathrm{D} 13 \mathrm{C}$ & $\mathrm{d} 15 \mathrm{~N}$ & $\mathrm{~d} 15 \mathrm{Nsd}$ & $\mathrm{CN}$ \\
\hline Emmer & Triticum dicoccum (type) & 5 & -23.2 & 0.09 & 17.1 & 6.1 & 0.18 & 17.3 \\
Spelt & Triticum spelta (type) & 5 & -22.3 & 0.09 & 16.2 & 6.0 & 0.18 & 18.8 \\
Millet & Panicum miliaceum & 20 & -9.8 & 0.11 & 3.3 & 5.3 & 0.18 & 21.8 \\
\hline
\end{tabular}

Neolithic Kleiner Anzingerberg site of the Jevišovice culture located in eastern Austria, the oldest finds of millet grains in fact make up less than $1 \%$ of crop grains (Kohler-Schneider and Caneppele 2009, Table 2). Nevertheless, it is, to date, the oldest find of proso millet in Europe from a radiocarbon-dated context (crop grains and bark were dated). The other find of proso millet in Neolithic feature from Miechów 3 site in S. Poland appeared to be Late Bronze Age after radiocarbon dating, which reflects postdepositional processes on that multiculture dry site (MuellerBieniek et al. 2017). Although proso millet probably appeared in the late third millennium BC in Europe, it became wellestablished during the second half of the second millennium $\mathrm{BC}$ (Valamoti 2016; Stevens et al. 2016). Proso millet is an Asiatic cultivar introduced to Europe in the Bronze Age (MotuzaiteMatuzeviciute et al. 2013; Spengler 2015; Murphy 2016; Valamoti 2016; Miller et al. 2016; Stevens et al. 2016). It spread from eastern China westwards to the Hexi Corridor about 2300 BC (Xinying et al. 2016). It is a summer crop that grows well in newly created fields, with high drought and heat tolerance and a short growing season of 60-100 days, not resistant to weed infestation, and was probably sown in previously uncultivated and unmanaged lands_-"new lands" (Pol. "nowina," Ger. "Neuland") (Lityńska-Zając and Wasylikowa 2005; Habiyaremye et al. 2017).

The assemblage from the Lipnik site is of the Middle Bronze Age (ca. 1400-1200 cal. BC, AMS millet grains: Poz-103203, $3040 \pm 3514 \mathrm{C}$ ) but it is exceptional owing to the large number of millet grains and their botanical context, suggesting a mixed subsistence strategy adopted by the settlers (d'Alpoim Guedes 2017). The single pit cannot give representative data about the paleoeconomy of the whole settlement and especially the whole archaeological culture. Additionally, assemblages of charred remains usually reflect only a small part of the plant remains deposited during the activity of the settlers (van der Veen 2007; Colledge and Conolly 2014; Mueller-Bieniek et al. 2015b) and thus reflect only part of the surrounding vegetation, mostly unintentionally or deliberately taken to the settlement. Nevertheless, on the basis of such a rich and well-preserved plant assemblage, we can assume that cultivation of hulled wheat and millet was practiced by the settlers, but that gathering also played a very important role. The grassland taxa, leaf buds, and twigs could represent remains of fodder, but we cannot exclude that it was also used as some kind of insulation (Behre and Jacomet 1991, p. 84). The wheat cultivation was rather of an intensive garden type (Bogaard 2004) as no typical winter crop weeds like Agrostemma githago were found, a plant already known north of the Carpathian from the Middle Neolithic (Lityńska-Zając 2005; Hellmund 2008; MuellerBieniek 2016). For discussion concerning intensive/non intensive cultivation through weed ecology, see also Kreuz and Schäfer (2011). The $\delta^{15} \mathrm{~N}$ values of wheat grains suggesting high/medium levels of manuring (Bogaard et al. 2013) support that view. The supposed mixed economic food strategy of the pit users, including plant cultivation, gathering, and assumed animal breeding (no bone remains were preserved there and on the other archeological sites located on the northern outskirts of the Carpathian Mountains due to the soil acidity, CzekajZastawny, Przybyła, Wilczyński pers. comm) was probably connected with early stages of the introduction of agriculture into forested or re-forested areas. The site was located in the newly settled area, transitional between the loess upland and the Carpathian foothills. The ancient users of the studied archeological feature probably used the same structure for storing diverse types of foods, including animal fodder. It is unclear whether the acorns were stored as food for humans or fodder for animals (Kapcia and Mueller-Bieniek 2017) but the final destination of the stored food might have depended on actual annual yields and conditions of storage, and may not have been definitely fixed as designed for human or animal (Jones 1996).

The detailed analysis of acorn remains from the Lipnik site and an overview of published acorn finds from Poland (Kapcia and Mueller-Bieniek 2017) suggested that their role in prehistoric times was relatively minor. It is possible that small fragments of those remains were systematically overlooked in our archeobotanical studies (compare Mason 1995). In the find from Lipnik, we cannot exclude the presence of Quercus pubescens, a tree of uncertain history in the Polish flora, associated with warmer climate and producing fruit much sweeter than those of the other two species native to Poland and commonly growing in the whole area of Poland (Q. robur, Q. petraea) (Luczaj et al. 2014). Nevertheless there are several methods for acorn food preparation, including those bitter types (for example Mason 2000; Deforce et al. 2009; Š́lková et al. 2011; Kapcia and Mueller-Bieniek 2017).

\section{Conclusion}

Despite relatively scarce paleoenvironmental data connected with the Middle Bronze Age human activity on the Kańczuga 
Plateau and agriculture development in that part of the Carpathian foothills, we can conclude that cultivation of at least millet (P. miliaceum) and hulled wheat (T. monococcum, T. dicoccum, and T. spelta) was known in the area. The cultivation of wheat was probably of the intensive type. Proso millet, as a typical summer crop with a short growing season, not resistant to weed infestation, could have been sown in previously uncultivated and unmanaged lands (Pol. "nowina," Ger. "Neuland'). Additionally, at that probable frontier zone of the Bronze Age agricultural system, gathering of wild plants, including acorns was important. As no bone remains were preserved at the site due to the soil conditions, the role of animal breeding can be deduced only indirectly. The remains of grassland plants as well as tree buds may indicate gathering of hay and leaf fodder. Nevertheless, a possibility that those plants and plant parts were collected as some kind of insulation cannot be excluded.

Acknowledgements The plant material was identified by Magda Kapcia under the supervision of Aldona Mueller-Bieniek. Both authors participated in the writing of the paper. The authors are grateful to Marcin S. Przybyła for valuable comments on the text; Wojciech Blajer, Magdalena Moskal-del Hoyo, and Marian Szewczyk for some of the photos; and Agnieszka Sojka for preparation of Figs. 1, 3, 4, 5, 6. The authors are also thankful to anonymous reviewers for their helpful comments. And last but not least, the authors thank Amanda Leon for improving the language of the text.

Funding This work was carried out under the auspices of the W. Szafer Institute of Botany of the Polish Academy of Sciences and financed by the National Science Center on the basis of decision number DEC-2013/ 10/M/HS3/00537.

Open Access This article is distributed under the terms of the Creative Commons Attribution 4.0 International License (http:// creativecommons.org/licenses/by/4.0/), which permits unrestricted use, distribution, and reproduction in any medium, provided you give appropriate credit to the original author(s) and the source, provide a link to the Creative Commons license, and indicate if changes were made.

\section{References}

Anderberg A-L (1994) Atlas of seeds and small fruits of NorthwestEuropean plant species (Sweden, Norway, Denmark, East Fennoscandia and Iceland) with morphological descriptions. Part 4. Resedeceae-Umbelliferae. Swedish Natural Science Research Council, Stockholm

Behre K-E (2008) Collected seeds and fruits from herbs as prehistoric food. Veg Hist Archaeobotany 17:65-73. https://doi.org/10.1007/ s00334-007-0106-x

Behre K-E (2017) Die Meeresspiegelschwankungen der vergangenen Jahrtausende und deren Bedeutung für das Siedlungsgeschehen an der deutschen Nordseeküste. In: Beiträge zur Besiedlungsgeschichte Nordwestdeutschlands zwischen Römischer Kaiserzeit und frühem Mittelalter. Niedersächsisches Institut für historische Küstenforschung (Hrsg.), Rahden/Westf., pp 13-30

Behre K-E, Jacomet S (1991) The ecological interpretation of archaeobotanical data. In: van Zeist W, Wasylikowa K, Behre K-E (eds) Progress in Old World Palaeoethnobotany. Balkema, Rotterdam, pp 81-108

Berggren G (1981) Atlas of seeds and small fruits of Northwest European plant species (Sweden, Norway, Denmark, East Fennoscandia and Iceland) with morphological descriptions. Part 3, SalicaceaeCruciferae. Swedish Natural Science Research Council, Stockholm

Bieniek A (2008) Pozostałości paszy zwierzęcej? Archeobotaniczne badania jamy 302 ze stanowiska 5 w Lipniku, pow. Przeworsk. In: Struktury osadnicze w epoce brązu i wczesnej epoce żelaza na obszarze podkarpackiej wysoczyzny lessowej między Wisłokiem i Sanem. Wydawnictwo Uniwersytetu Jagiellońskiego, Kraków, pp 319-326

Bogaard A (2004) Neolithic farming in Central Europe: an Archaeobotanical study of crop husbandry practices. Routledge, London

Bogaard A, Fraser R, Heaton THE, Wallace M, Vaiglova P, Charles M, Jones G, Evershed RP, Styring AK, Andersen NH, Arbogast RM, Bartosiewicz L, Gardeisen A, Kanstrup M, Maier U, Marinova E, Ninov L, Schafer M, Stephan E (2013) Crop manuring and intensive land management by Europe's first farmers. Proc Natl Acad Sci 110: 12589-12594. https://doi.org/10.1073/pnas.1305918110

Bojnanský V, Fargašová A (2007) Atlas of seeds and fruits of central and east-European flora: the Carpathian Mountains region. Springer, Dordrecht

Brinkkemper O, Weeda EJ, Bohncke SJP, Kuijper WJ (2007) The past and present occurrence of Elatine and implications for palaeoenvironmental reconstructions. Veg Hist Archaeobotany 17(1):15-24

Colledge S, Conolly J (2014) Wild plant use in European Neolithic subsistence economies: a formal assessment of preservation bias in archaeobotanical assemblages and the implications for understanding changes in plant diet breadth. Quat Sci Rev 101:193-206. https://doi.org/10.1016/j.quascirev.2014.07.013

Czopek S (2003) "Rzeszowskie" skupisko osadnicze kultury trzcinieckiej. In: Gancarski J (ed) Epoka brązu i wczesna epoka żelaza w Karpatach polskich: materiały z konferencji. Muzeum Podkarpackie w Krośnie, Krosno, pp 139-150

d'Alpoim Guedes J (2017) Did foragers adopt farming? A perspective from the margins of the Tibetan Plateau Quat Int 489:91-100. https://doi.org/10.1016/j.quaint.2016.12.010

Deforce K, Bastiaens J, Van Calster H, Vanhoutte S (2009) Iron Age acorns from Boezinge (Belgium): the role of acorn consumption in prehistory. Archaologisches Korresp 39:381-392

van der Veen M (2007) Formation processes of desiccated and carbonized plant remains - the identification of routine practice. J Archaeol Sci 34:968-990. https://doi.org/10.1016/j.jas.2006.09.007

Dobrzański B, Konecka-Betley K, Kuźnicki F, Zawadzki S (1999) Mapa gleb Polski. In: Zawadzki S (ed) Gleboznawstwo, 4th edn. Państwowe Wydawnictwo Rolnicze i Leśne, Warszawa

Ellenberg H, Weber H, Dull R, et al (1991) Zeigerwerte von Pflanzen in Mitteleuropa. Scripta Geobotanica, 18, 1-248. Hill MO Preston CD Roy DB 2004 Plantatt Attrib Br Ir Plants Status Size Life Hist Geogr Habitats Cent Ecol Hydrol Monks Wood Cambs

Habiyaremye C, Matanguihan JB, D’Alpoim Guedes J, Ganjyal GM, Whiteman MR, Kidwell KK, Murphy KM (2017) Proso millet (Panicum miliaceum L.) and its potential for cultivation in the Pacific northwest, U.S.: a review. Front Plant Sci 7. https://doi.org/ 10.3389/fpls.2016.01961

Hajnalová M (2012) Archeobotanika doby bronzovej na Slovensku: štúdie ku klime, prírodnému prostrediu, pol'nohospodárstvu a paleoekonómii. Univerzita Konštantína Filozofa, Nitra

Helbaek H (1958) The last meal of Grauballe man. KUML Årb Jysk Arkæol Selsk 1958:83-116

Hellmund M (2008) The Neolithic records of Onopordum acanthium, Agrostemma githago, Adonis cf. aestivalis and Claviceps purpurea in Sachsen-Anhalt, Germany. Veg Hist Archaeobotany 17:123-130. https://doi.org/10.1007/s00334-008-0180-8 
Jacomet S, Brombacher C, Dick M (1989) Archäobotanik am Zürichsee: Ackerbau, Sammelwirtschaft und Umwelt von neolithischen und bronzezeitlichen Seeufersiedlungen im Raum Zürich, Ergebnisse von Untersuchungen pflanzlicher Makroreste der Jahre 19791988. Komm. Orell Füssli, Zürich

Jasiewicz A (1963) Podrodzina: Rhinanthoideae. In: Pawłowski B (ed) Flora Polska. Rośliny naczyniowe Polski i ziem ościennych. Państwowe Wydawnictwo Naukowe, WarszawaKraków, pp 339-388

Jones G (1996) Distinguishing food from fodder in the Archaeobotanical record. Environ Archaeol 1:95-98. https://doi.org/10.1179/env. 1996.1.1.95

Kapcia M, Mueller-Bieniek A (2017) Żołędzie (Quercus sp.) jako źródło pożywienia i paszy w pradziejowej gospodarce. Fragm Flor Geobot Pol 24:133-155

Katz N, Katz S, Kipiani M (1965) Atlas i oprjedielitjel plodov i semian vstreczajuszczychsia v czetvjerticznych odlozeniach SSSR. Nauka, Moskva

Katzenberg MA (2008) Stable isotope analysis: a tool for studying past diet, demography, and life history. In: Katzenberg MA, Saunders SR (eds) Biological anthropology of the human skeleton. John Wiley \& Sons, Inc., pp 411-441

Klimek K, Lanczont M, Nogaj-Chachaj J (2006) Historical deforestation as a cause of alluviation in small valleys, subcarpathian loess plateau, Poland. Reg Environ Chang 6:52-61. https://doi.org/10.1007/ s10113-005-0008-3

Kohler-Schneider M (2001) Verkohlte Kultur- und Wildpflanzenreste aus Stillfried an der March als Spiegel spätbronzezeitlicher Landwirtschaft im Weinviertel, Niederösterreich. VÖAW, Verlag

Kohler-Schneider M, Caneppele A (2009) Late Neolithic agriculture in eastern Austria: archaeobotanical results from sites of the Baden and Jevišovice cultures (3600-2800 b.c.). Veg Hist Archaeobotany 18: 61-74. https://doi.org/10.1007/s00334-007-0129-3

Kołaczek P (2011) 12 millennia of climatic and human induced vegetation changes in the lower san valley near Jarosław (SE Poland) in the light of pollen analysis. Stud Quat 28:25-39

Kondracki J (2000) Geografia regionalna Polski, 2nd edn. Wydawnictwo Naukowe PWN, Warszawa

Koźmiński C, Michalska B (2001) Atlas klimatycznego ryzyka uprawy roślin w Polsce. Akademia Rolnicza, Szczecin

Kreuz A, Schäfer E (2002) A new archaeobotanical database program. Veg Hist Archaeobotany 11:177-180. https://doi.org/10.1007/ s003340200019

Kreuz A, Schäfer E (2011) Weed finds as indicators for the cultivation regime of the early Neolithic Bandkeramik culture? Veg Hist Archaeobotany 20:333-348. https://doi.org/10.1007/s00334-011-0294-2

Kulpa W (1974) Nasionoznawstwo chwastów, 2nd edn. Państwowe Wydawnictwo Rolnicze i Leśne, Warszawa

Łanczont M, Nogaj-Chachaj J, Klimek K (2001) Potencjał środowiska naturalnego przykarpackiej wysoczyzny lessowej dla osadnictwa neolitycznego. In: Gancarski J, Muzyczuk A (eds) Neolit i początki epoki brązu w Karpatach polskich: materiały sesji naukowej, Krosno, 14-15 grudnia 2000 r. Muzeum Podkarpackie w Krośnie, Krosno, pp 173-199

Łanczont M, Klimek K, Nogaj-Chachaj J (2003) Holoceńskie przemiany środowiska przyrodniczego Wysoczyzny Kańczuckiej - zarys wyników badań interdyscyplinarnych. In: Łanczont M, NogajChachaj J (eds) FNP dla archeologii. Podsumowanie programów TRAKT i ARCHEO. Fundacja na Rzecz Nauki Polskiej and Uniwersytet Marii Curie-Skłodowskiej w Lublinie, Lublin, pp 111-116

Li C, Dong Y, Liu M, Lu P, Li W, Wang Y, Cui X, Zhou H, Xu Y (2016) Ancient DNA analysis of Panicum miliaceum (broomcorn millet) from a bronze age cemetery in Xinjiang, China. Veg Hist Archaeobotany 25: 469-477. https://doi.org/10.1007/s00334-016-0561-3
Lityńska-Zając M (2005) Chwasty w uprawach roślinnych w pradziejach i wczesnym średniowieczu. Instytut Archeologii i Etnologii Polskiej Akademii Nauk, Kraków

Lityńska-Zając M, Wasylikowa K (2005) Przewodnik do badań archeobotanicznych. Sorus, Poznań

Łuczaj Ł, Adamczak A, Duda M (2014) Tannin content in acorns (Quercus spp.) from Poland. Dendrobiology 72:103-111

Mamakowa K, Wójcik A (1999) Profil utworów rzecznych i jeziornych w rejonie Markowej. In: IV Konferencja stratygrafii plejstocenu Polski 'Czwartorzęd wschodniej części Kotliny Sandomierskiej', Czudec, 31.08-4.09.1999. Państwowy Instytut Geologiczny, Kraków, pp 130-140

Mason SLR (1995) Acornutopia? Determining the role of acorns in past human subsistence. In: Wilkins J, Harvey D, Dobson M (eds) Food in antiquity: studies in ancient society and culture. University of Exeter Press, Exeter, pp 12-24

Mason SLR (2000) Fire and mesolithic subsistence - managing oaks for acorns in Northwest Europe? Palaeogeogr Palaeoclimatol Palaeoecol 164:139-150. https://doi.org/10.1016/S0031-0182(00)00181-4

Matuszkiewicz W (2001) Przewodnik do oznaczania zbiorowisk roślinnych Polski. Wydawnictwo Naukowe PWN, Warszawa

Matuszkiewicz JM (2008) Potencjalna roślinność naturalna Polski

Maurizio A (1926) Pożywienie roślinne i rolnictwo w rozwoju dziejowym, Reprint 2017. Wydanie z zasiłku Ministerstwa Wyznań Religijnych i Oświecenia Publicznego- Nakładem Kasy Malinowskiego, Warszawa

Miller NF, Spengler RN, Frachetti M (2016) Millet cultivation across Eurasia: origins, spread, and the influence of seasonal climate. The Holocene 26:1566-1575. https://doi.org/10.1177/0959683616641742

Mirek Z, Piękoś-Mirkowa H, Zając A, Zając M (2002) Flowering plants and Pteridophytes of Poland. A checklist, 1st edn. Instytut Botaniki im. W. Szafera, Polska Akademia Nauk, Kraków

Mizianty M (1978) Variability of Rhinanthus serotinus (Schönh.) Oborny in Poland. Fragm Flor Geobot 24:387-425

Moskal-del Hoyo M, Lityńska-Zając M, Korczyńska M, Cywa K, Kienlin TL, Cappenberg K (2015) Plants and environment: results of archaeobotanical research of the Bronze Age settlements in the Carpathian foothills in Poland. J Archaeol Sci 53:426-444. https:// doi.org/10.1016/j.jas.2014.10.024

Motuzaite-Matuzeviciute G, Staff RA, Hunt HV et al (2013) The early chronology of broomcorn millet (Panicum miliaceum) in Europe. Antiquity 87:1073-1085

Mueller-Bieniek A (2011) Makroszczątki roślinne z wielokulturowego stanowiska Pęcławice 5, gmina Piątek, powiat Łęczyca, województwo łódzkie. In: Dziubek E, Marchelak I, Tyszler L (eds) Ratownicze badania archeologiczne na stanowisku 5 w Pęcławicach, pow. Łęczyca, woj. łódzkie (trasa autostrady A-1). Fundacja Badań Archeologicznych im. Profesora Konrada Jażdżewskiego and Muzeum Archeologiczne w Łodzi, Łódź, pp 353-376

Mueller-Bieniek A (2016) Badania materiałów roślinnych związanych z kulturą pucharów lejkowatych w rejonie Brześcia Kujawskiego i Osłonek. In: In: R. Grygiel. Neolit i początki epoki brązu w rejonie Brześcia Kujawskiego i Osłonek. Tom III. Środkowy i późny neolit, kultura pucharów lejkowatych. Fundacja Badań Archeologicznych Imienia Profesora Konrada Jażdżewskiego, Łódź, pp 753-769

Mueller-Bieniek A, Walanus A (2012) Codzienność mieszkańców średniowiecznego Krakowa w świetle analizy statystycznej danych archeobotanicznych. In: Mueller-Bieniek A (ed) Rośliny w życiu codziennym mieszkańców średniowiecznego Krakowa. Instytut Botaniki im. W. Szafera, Polska Akademia Nauk, Kraków, pp 115-165

Mueller-Bieniek A, Woch M (2012) Właściwości użytkowe i ekologiczne oraz kody roślin znalezionych w warstwach archeologicznych średniowiecznego Krakowa. In: Rośliny w życiu codziennym mieszkańców średniowiecznego Krakowa. Instytut Botaniki im. W. Szafera, Polska Akademia Nauk, Kraków, pp 167-184 
Mueller-Bieniek A, Walanus A, Zaitz E (2015a) Cultivated plants in medieval Kraków (Poland), with special reference to amaranth (Amaranthus lividus L. cf. var lividus) and ruderal communities. Acta Palaeobot 55:97-114. https://doi.org/10.1515/acpa-2015-0003

Mueller-Bieniek A, Walanus A, Zaitz E (2015b) Cultivated plants in medieval Kraków (Poland), with special reference to amaranth (Amaranthus lividus L. cf. var lividus) and ruderal communities. Acta Palaeobot 55:97-114. https://doi.org/10.1515/acpa-2015-0003

Mueller-Bieniek A, Moskal-del Hoyo M, Kapcia M, Przybyła MM (2017) Traces of supposed Neolithic plant husbandry in the multicultural site 3 at Miechów, southern Poland. In: Valde-Nowak P, Sobczyk K, Nowak M, Źrałka J (eds) Amici magistro et collegae suo Ioanni Christopho Kozłowski dedicant. Alter, Uniwersytet Jagielloński Kraków

Murphy C (2016) Finding millet in the Roman world. Archaeol Anthropol Sci 8:65-78. https://doi.org/10.1007/s12520-015-0237-4

Musierowicz A (ed) (1958) Mapa gleb Polski 1 1(000):000

O'Leary MH (1981) Carbon isotope fractionation in plants. Phytochemistry 20:553-567. https://doi.org/10.1016/0031-9422(81)85134-5

Pearsall DM (2009) Paleoethnobotany: a handbook of procedures, 2nd edn. Routledge

Pokorná A, Dreslerová D, Křivánková D (2011) Archaeobotanical database of the Czech Republic, an interim report. Interdiscip Archaeol Nat Sci Archaeol 2:49-53

Przybyła MS, Blajer W (2008) Struktury osadnicze w epoce brązu i wczesnej epoce żelaza na obszarze podkarpackiej wysoczyzny lessowej między Wisłokiem i Sanem. Wydawnictwo Uniwersytetu Jagiellońskiego, Kraków

Rutkowski L (2008) Klucz do oznaczania roślin naczyniowych Polski niżowej, 1st edn. Wydawnictwo Naukowe PWN, Warszawa

Š́álková T, Divišováa M, Kadochová $S$ et al (2011) Acorns as a food resource. An experiment with acorn preparation and taste. IANSA 2:133-141. https://doi.org/10.24916/iansa.2011.2.6

Snowarski M (2002) Atlas roślin Polski atlas-roslin.pl - Atlas of vascular plants of Poland. https://www.atlas-roslin.pl/pelna/index.html. Accessed 15 Dec 2017

Spengler RN (2015) Agriculture in the central Asian Bronze Age. J World Prehistory 28:215-253. https://doi.org/10.1007/s10963-015-9087-3

Starkel L, Michczyńska DJ, Krapiec M, Margielewski W, Nalepka D, Pazdur A (2013) Progress in the holocene chronoclimatostratigraphy of polish territory. Geochronometria 40:1-21. https://doi.org/10.2478/s13386-012-0024-2
Stevens CJ, Murphy C, Roberts R, Lucas L, Silva F, Fuller DQ (2016) Between China and South Asia: a middle Asian corridor of crop dispersal and agricultural innovation in the Bronze Age. The Holocene 26: 1541-1555. https://doi.org/10.1177/0959683616650268

Szymanowski T (1974) Rozpoznawanie drzew i krzewów ozdobnych w stanie bezlistnym. Państwowe Wydawnictwo Rolnicze i Leśne, Warszawa

Valamoti SM (2016) Millet, the late comer: on the tracks of Panicum miliaceum in prehistoric Greece. Archaeol Anthropol Sci 8:51-63. https://doi.org/10.1007/s12520-013-0152-5

Velichkevich FY, Zastawniak E (2008) Atlas of the Pleistocene vascular plant macrofossils of central and Eastern Europe, part 2: herbaceous Dicotyledones. Instytut Botaniki im. W. Szafera, Polska Akademia Nauk, Kraków

Wallace M, Jones G, Charles M, Fraser R, Halstead P, Heaton THE, Bogaard A (2013) Stable carbon isotope analysis as a direct means of inferring crop water status and water management practices. World Archaeol 45:388-409. https://doi.org/10.1080/00438243. 2013.821671

Warden L, Moros M, Neumann T, Shennan S, Timpson A, Manning K, Sollai M, Wacker L, Perner K, Häusler K, Leipe T, Zillén L, Kotilainen A, Jansen E, Schneider RR, Oeberst R, Arz H, Sinninghe Damsté JS (2017) Climate induced human demographic and cultural change in northern Europe during the mid-Holocene. Sci Rep 7:15251. https://doi.org/10.1038/s41598-017-14353-5

Wasylikowa K, Lityńska-Zając M, Bieniek A, Gluza I (2002) Archeobotaniczne badania nad trawami. In: Frey L (ed) Polska Ksiega Traw. Instytut Botaniki im. W. Szafera, Polska Akademia Nauk, Kraków, pp 39-52

Xinying Z, Xiaoqiang L, Dodson J, Keliang Z (2016) Rapid agricultural transformation in the prehistoric Hexi corridor, China. Quat Int 426: 33-41. https://doi.org/10.1016/j.quaint.2016.04.021

Zając M, Zając A (2015) Survival problems of archaeophytes in the polish flora. Biodivers Res Conserv 35:47-56. https://doi.org/10. 2478/biorc-2014-0015

Zernickaya V, Klimek K, Łanczont M, Nogaj-Chachaj J (2003) Holoceńska historia roślinności i ślady działalności człowieka w rejonie Cieszacina Wielkiego. In: Łanczont M, Nogaj-Chachaj J (eds) FNP dla archeologii. Podsumowanie programów TRAKT i ARCHEO. Fundacja na Rzecz Nauki Polskiej and Uniwersytet Marii Curie-Skłodowskiej w Lublinie, Lublin, pp 121-123

Zohary D, Hopf M, Weiss E (2012) Domestication of plants in the old world, 4th edn. Oxford University Press, Oxford 